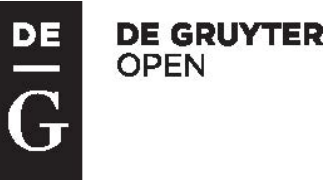

LINGUACULTURE 2, 2013

\title{
THE LECTURER COACH
}

\author{
PAUL CATTEEUW \\ Charlemagne University College - Antwerp (Belgium)
}

\begin{abstract}
:
Teaching has experienced dramatic changes in the last few decades. From ex cathedra lectures to the use of social media in a classroom is a giant leap for both lecturer and students. Paul Catteeuw, lecturer of intercultural communication at Charlemagne University College in Antwerp (Belgium), has explored the boundaries of the newest methods in competence teaching, but did not forget the knowledge component of the tuition process. As he developed a framework of intercultural competence for business students, he rethought his role as a lecturer. He moved from the central omniscient rostrum position to a place at the side of the classroom as a facilitator, coaching students in a new creative learning environment making use of activating learning forms such as zoom sessions, teamwork and many others. At the same time he introduced different forms of assessment. In this article Catteeuw describes the intensive, sometimes laborious process of the lecturer coach.
\end{abstract}

Keywords: intercultural communication, learning environment, portfolio, coaching, evaluation.

\section{Introduction}

Globalisation has been a buzzword for quite some time. But whereas everybody talked about it in the seventies and eighties of the former century, globalisation became tangible since the fall of the wall in 1989. The world opened up rapidly and contacts with different cultures multiplied at an increasing speed. This was enhanced drastically by information technology and the revolution of the social media. Another factor is immigration, which renders a completely mixed society in different fields.

This globalisation consequently has a profound influence on the business world. Hardly any business is still only local. Providers and clients can live in different worlds, but still need to work together.

In the past decades the success of contacts was very often based on (personal) experience. By trial and error, with ups and downs. But society and business ask for professionalism. Training in this field was introduced, young professionals are now better prepared to enter the international (read: 
intercultural) market. But this needed a different approach to teaching. From this angle we have tried to develop a framework of reference for intercultural competence because we are convinced of the fact that you can train intercultural competence, but that there is need for a theoretical basis to master this competence. Simultaneously we want to illustrate this with an example of a good practice. This article will deal with the changes we undertook to implement this kind of tuition as a compulsory subject for bachelor students business administration at Charlemagne University College (Antwerp - Belgium). Including all the pitfalls.

\section{Intercultural communication}

On a trip to China a short while ago we were surprised at the way the students reacted to our way of teaching. Walking around, using prezi or powerpoint presentations, asking questions, pointing out aspects, raising topics, provoking discussions, asking cooperation. These actions, which seem normal and logical in a setting of contemporary Flemish tuition at universities and university colleges, were met with a lot of scepticism. This dynamic form of teaching was totally strange and unknown to an audience of Chinese bachelor students at the Dalian Nationalities University, where they were still accustomed to repeated ex cathedra tuition.

It felt awkward, but at the same time it gave me the possibility to reflect on the enormous evolution of the art of teaching in the last few decades. In the sixties West European tuition also suffered from heavy ex cathedra teaching with the omniscient and omnipotent teacher at the centre of things. With hints of new methods ${ }^{\mathrm{ii}}$ (such as group work) slowly creeping into the system of education that provided knowledge to students. As long as you knew, you were counted in. The lecturer had to lecture, the student ${ }^{\text {iii }}$ had to absorb subject material. And at the end of the semester a parrot exam decided on success or failure. Academic discourse with students was as rare as a white elephant.

Gradually however we grew away from this form of teaching. Educators realized that knowledge was not sufficient for future professionals; also competences and skills were needed. This actuated an ardent discussion between the knowledge supporters and the competence believers, whereas a balanced association between those two components is the logic of events: no knowledge without competence and vice versa.

New forms of education and assessment were being introduced: projectoriented, demand-oriented, competence education. Lots of experiments were being done; success and failure went hand in hand. Central however was the dethronisation of the lecturer as the centre of his learning universe. He was not pushed aside, but gradually pushed to the side of the education business. He became a facilitator, a coach who helped and supported the learning process. 
Social constructivism was adapted in educational matters. Students were no longer passive, material absorbing objects, but active, material handling subjects. They were given the essential bricks to build their own house, but at the same time guided in building that house. At the same time new forms of assessment were being introduced and tested. This changed and the changing role of the lecturer enhances a thorough paradigm shift in the teaching environment. From chalk and blackboard to - amongst others - electronic devices and social media, it is not always an easy, but certainly a long step. Within a strong learning environment tuition should be activating and student-oriented, aiming at making students competent and linking with the future labour market. This implies that the construction of knowledge is a central factor and that the lecturer supports, guides and facilitates.

This requires other competences from the lecturer and makes him quite a different teacher in comparison with the teacher of 50 years ago. Or with our Chinese colleague at Dalian Nationalities University who swears by his way of teaching, even though it is not our intention at all to be patronizing.

In the scope of this article we will try to explain how we tried to implement this learning environment in our courses of intercultural communication ${ }^{\text {iv }}$. Therefore, this paper is largely descriptive, as it is the account of how this altered way of teaching has been introduced in our lessons. It is a very personal and subjective reflection on the different methods we introduced and used and the advantages and drawbacks we experienced en route. This course was a compulsory part of the curriculum in the first bachelor, with large groups of about 50-60 students.

\section{Creative learning environment methods}

\section{Activating forms}

\section{Introductory questions, zoom sessions and discussion}

One of the better ways to start a teaching session turned out to be the use of introductory questions. Thus, you can introduce the topic in a lighter way, avoiding theoretical schemes or explanations.

These questions can vary from the student's own experiences to opinions about certain topics. To this purpose you can use a plain question and answer moment. Or you can introduce a buzz session, i.e. a small informal group discussion on a certain topic. Or you can start a class discussion.

Advantages:

- The student's thought process is activated.

- The student's involvement is called upon.

- Classroom presence is stimulated because of active participation.

- Possibility of direct communication. 
Disadvantages:

- Time investment by the teacher as the preparation time is extended.

- Noise can be disturbing for other groups and lead to distraction or nonparticipation.

- With buzz sessions as a lecturer you do not immediately have insight into the structure and the value of students' answers.

\section{Solution oriented thinking}

The lecturer gives a short introduction on the working method and gives then a task that can be worked out individually or in groups. A practical example is here the three-step method of David Pintov, which was used during contact hours. The method is explained to the students; the theory is backed up by examples. They are then given cases to be solved along the lines of this theory.

Advantages:

- The preliminary explanation of the method assures the lecturer that he has control over the theory and makes sure that he conveys it to his audience in a suitable way.

Disadvantages:

- The necessary control over the groups is hard to carry through when you have to monitor large groups in a hands-on situation.

\section{Actuality}

With the presence of the social media and other sources the actuality can very easily be used in different forms. Since a subject as intercultural communication is very suitable for actuality, it is only natural that you make use of it.

Advantages:

- Students learn to make professional use of social media such as LinkedIn and Vimeo, rather than Facebook and youtube.

- Students learn to make professional use of discussion fora as a preparation for later workgroups and conference calls.

- The subject is made topical by using up-to-date examples and stories.

- The student feels involved with the chosen actuality, as he knows about the items through other channels.

Disadvantages:

- Dependence on the actuality.

Preparatory tasks

Students are being given tasks they have to prepare, alone or in a group, as a preparation for the next lesson.

Advantages: 
- The student is well prepared to follow the courses as he has studied the subject by preparing the task given to him.

- No further preparation is needed, which gives the lecturer more space during contact hours.

- Good cognitive assimilation of the contents.

Disadvantages:

- Because of the number of students constant task control is very difficult.

\section{Use of multimedia}

The millennium generation (or generation $\mathrm{Y}$ ) is also the image generation. Whereas the generation $\mathrm{X}$ received its education mainly through books, manuals, readers, ..., written stuff, today's students do tend to drop reading materials. They are highly influenced by the surrounding world, offering all kinds of visual media. Reading becomes rare and many public libraries have been or are being closed ${ }^{\mathrm{vi}}$.

Theory and examples have therefore been backed up or clarified by short films, taken from the rich Internet supply (youtube and Vimeo are a vast and ever growing storage room).

Advantages:

- The student's span of active listening attention seems to have diminished. Short video interruptions activate the attention and keep their mind on the lesson.

- There is an active appeal to visual and audile memory as students are part of a visual culture and therefore tend to absorb better.

Disadvantages:

- ICT and infrastructure: as a teacher you have to depend very much on the infrastructure. But things can - and will - go wrong, so you have to be prepared for that situation and have back up material at hand.

- Digital natives: working with ICT means that the lecturer must also be acquainted with ICT, because students do not tolerate a moderate handling of the equipment. This demands extra efforts from the lecturer.

- Older lecturers (being educated in a book culture) will have to learn to deal with a visual culture. But if you succeed in doing this, the drawback can be turned into an advantage of acceptance by the students.

\section{Groupwork and reflection}

\section{Reflection groups}

In order to prepare students for the tasks students formed groups of 10-15 people in which they could reflect upon the task, but even more importantly, on the way they had to tackle the method. As a connecting thread they had a framework of reference in which the intercultural competence was written down. 
To think about method and development made students responsible for their actions, as they are part of a group and as these meetings were also the basis for peer assessment. knowledge.

Group reflection starts with self-reflection, which leads to self-

\section{Teamwork}

Teamwork has undergone a drastic change in the heads of the student of today. We noticed that we had to reinvent teamwork for them as they filled this in in a complete different way as we had intended.

Without coaching students split up the tasks into individual bits and agree upon a date to meet again and assemble the results. The concept that teamwork implies working in and cooperating with a team at all times instead of bringing individual results together in a final session seems a strange idea to the modern student, as he keeps saying that he has all facilities to keep in touch with his peers (internet, chatrooms, skype, ...). But experience showed that this wasn't reality, as the ICT means were only used to fix a date and not to work together.

So we had to change their attitude towards group work and make them realise that within a team each player has his role and that this form of teamwork tries to emulate the situation on the shop floor.

\section{Feedback}

At different points in the process we built in moments of feedback on different levels.

Feedback to the reflection groups focused on the process of the task, rather than on the result.

There was always the possibility of personal feedback, if needed. This happened mostly when problems with other group members arose.

This kind of talks led to peer feedback. Students were encouraged to discuss a problem within their own reflection group or to start a discussion about certain issues on the discussion fora that were made available for them on the electronic platform of the university college ${ }^{\text {vii }}$.

Further problems could be discussed with the lecturer, through mail or in a personal talk.

\section{Evaluation}

Evaluating intercultural competence is an extremely difficult business ${ }^{\text {viii }}$. Teaching ICC is done in a void, a kind of laboratory situation in which it is very difficult to really assess the student's competence. The proof of the competence 
is in the practice, which means in the contacts of the young professional. In a setting of education you can only try to emulate real situations.

But then again, as a lecturer you have to assess your students and you have to choose for the right means, as a written exam on knowledge was out of the question. We chose for a process portfolio and took care to avoid mistakes in assessing.

\section{Criteria}

In order to assess as objectively as possible we had to focus on the criteria ${ }^{\mathrm{ix}}$ :

- Validity

It is very important to measure what you want to measure. In our case we didn't want to measure the knowledge about intercultural communication, but we wanted to measure how interculturally competent students were and how they developed during the course.

- Reliability:

You cannot afford mistakes in measuring. We tried to accomplish that by the used of a competence grid.

- Transparency

It is very important to keep the students posted during the course as the assessment of intercultural competence doesn't run along the lines of correct/wrong tests.

- Measurability:

This is probably the hardest criterion as it is not always $100 \%$ clear what you can/should measure. To this end we created the framework based on a general intercultural competence.

To explain these criteria to the students we used a straightforward example from medicine.

If you have flu, you can go to a doctor. He will take your temperature with a thermometer (measurability) and show your temperature (transparency). As a patient you rely on the correct functioning of your doctor's thermometer (reliability) to take your temperature because you have flu (validity).

If you have broken your leg however, the doctor will not take your temperature (however transparent, reliable and measurable this action may be), because this action would not be valid, as running a temperature is not a symptom of a fractured leg. 


\section{Portfolio}

The use of a portfolio ${ }^{\mathrm{x}}$ is a thread within the course. The concept of this portfolio was worked out by MarleenCoutuer ${ }^{\mathrm{xi}}$ and has been used as a basis for different subjects in the curriculum.

A professional bachelor is expected to be available and employable on the shop floor immediately. According to Jan van Tartwijk $k^{\text {xii }}$ [the portfolio in higher education] refers to instruments that have in common that they make transparent the unique development of a student or the result of that development [at a certain moment]. This enhances the quality of the work. At the same time the portfolio enables the lecturer to support and tutor the development of the student's competences (development portfolio) and makes the process of development transparent. For a lecturer portfolios have an advantage in both tutoring (development portfolio) and assessment (assessment portfolio). A development portfolio shows the student's (formative) process, whereas an assessment portfolio shows the (summative) product of the student's efforts.

In this methodology you can see the shift of role from the traditional teacher to that of a facilitator-coach ${ }^{\text {xiii }}$. At the end of the path the student can convert his portfolio into an application or presentation portfolio providing potential employers insight into his acquired competences as part of a curriculum vitae. And thus this portfolio becomes the starting point for lifelong learning, a conditio sine qua non in today's professional world.

Though working with portfolios is a widespread method it does not only offer advantages to the students as was clearly shown by an analysis of the system $^{\text {xiv }}$.

Advantages:

- The biggest advantage of working with this kind of portfolio is the stimulus for reflection. Students do not only learn upon the task, they also reflect on themselves and on their peers. This is a tremendous asset when entering the shop floor.

- A development portfolio clearly shows the evolution of the student involved

- The use of a portfolio clearly makes the student more creative as he has more space to arrange his portfolio to his liking.

- A portfolio is not a waste product as it can lead to a presentation portfolio that can be included in the job seeker's curriculum vitae and maintained during his professional career.

Disadvantages:

- Multitude of portfolios: as portfolios tend to be a whim of fashion we should heed the fact that students shouldn't be snowed under with portfolios so that they will lose their belief in this method. 
- Working with portfolios is very labour intensive, both for lecturer and student.

- Students are not yet satisfactorily acquainted with self-reflection, which is time consuming during the learning process.

\section{Assessment}

For students one of the most astonishing changes were the different forms of assessment, in which a lot of attention is devoted to reflection on the own competence and the own learning process. If you reflect, you will learn your strengths and weaknesses. And if you recognize your weaknesses, you can work on them.

\section{Self-assessment}

With the help of an assessment grid students have to assess their own level of competence during the process at three different moments: beginning, middle and end. This grid is based upon the framework. The self-assessment is not quoted, but shows the evolution of a student during the course.

Advantages:

- The grids for self-assessment are very transparent and are part of the student's portfolio.

- Having to reflect on yourself is a very valuable exercise in selfknowledge.

- The evolution in acquiring competence can be shown by comparing the grids at different stages.

- Self-assessment makes the student responsible for his own attitude.

Disadvantages:

- As self-assessment is not self evident for students, the lack of practical experience and critical insight is a hindrance and therefore the process of self-assessment has to be tutored.

- Also, because of this lack of experience students tend to over- or underestimate $^{\mathrm{xv}}$ themselves.

\section{Peer assessment}

Students work together in reflection groups and for tasks teamwork is implied. These forms of cooperation induce peer assessment. They can evaluate their peers, if needed, for different reasons: lack of interest of another student, outstanding performance within the group, unsocial behaviour, ... This form of assessment gives students the possibility to vent their criticism, either positive or negative.

This form of (formative) assessment is done along the lines of given criteria and within a sphere of complete confidentiality between the student and 
the lecturer. To ensure that a student does not use this form of assessment as a dishonest form of settling (mutual) accounts, deviant quotations have to be accounted for very clearly.

Advantages:

- Peer assessment is a valuable step in developing social skills and a worthwhile step towards a professional attitude, which will be needed on the shop floor, where this kind of assessment is normal procedure.

- Peer assessment is a useful exercise in reflection, not only about your peer, but also about the working process.

- Peer assessment makes the assessor responsible for his own attitude but at the same time for his team.

Disadvantages:

- Again, lack of practical experience and critical insight can lead to poor assessment, therefore tutoring is strongly advisable.

- Again here, there is the danger of over- or underestimation, as students find it hard to assess their own level.

\section{Co-assessment}

Completely new to our students was (summative) co-assessment in which the students could partly grade themselves. We let the students propose a grade for their work. They should however account for that quotation and we left the possibility for discussion about that grade.

Advantages:

- This way of assessing heightens the commitment of the student, as he is involved in the process of grading his own work.

- As a lecturer you get a different angle to look at the performance of a student through his assessment of his portfolio.

- You make the student co-responsible for his result, which can prevent discussions, as objective assessment of intercultural competence is an extremely difficult process.

- Again, reflection is at the centre of this process.

- Learning by assessing is a very good preparation for later work on the shop floor.

- As a talk with the lecturer is always possible, the co-operation between lecturer and student is much closer than in more traditional forms of grading.

Disadvantages:

- The lack of practical experience and critical insight again play an important part in the assessment process.

- As in the other forms of assessment, over- and underestimation are important here as well. 
Shortcomings:

Though the motivation to take voluntary part in this co-assessment is great, there were some shortcomings because both lecturer and students were not really prepared for this sort of assessment.

- For students it seemed to be very hard to define their learning outcomes, as they reflected much more on how long they had worked, rather than on the outcomes of their tasks and how they had functioned.

- It was at the same time hard to define learning activities for precisely the same reason.

- The follow up was difficult, because very time consuming.

\section{Permanent process assessment}

The whole process of learning was permanently assessed from different angles as closely as possible. Possible quotations could be seen in an open gradebook and discussed in the feedback groups or in a personal task.

Advantages:

- The openness of grading is much valued by students as they can follow their own process.

- At the same time students can control the correctness of the grading.

Disadvantages:

- The work load for the lecturer is enormous given the number of students.

Why have we chosen this complex form of assessment?

- The biggest factor is the harmony of the invested labour and the different assessment forms. Students can see the link between both and they do value this.

- Because assessing intercultural competence is a difficult problem, process evaluation is a good option to reach a balanced result.

- Big groups lead to a large volume of work and can be the cause of poor process evaluation. The different forms of assessment by the student and by his peers can help complete the overall picture and avoid blatant mistakes in assessing.

Advantages:

- Balanced results.

- The satisfaction of both lecturer and students.

Disadvantages:

- Controllability: the amount of data is sometimes hard to handle and must be kept under control.

- The work load for the lecturer is enormous when you have to deal with big groups, as our case shows clearly. 


\section{Conclusion}

In this article we have tried to roll out the change we have undergone as a lecturer during the last four decades. Whereas teaching during the seventies and the eighties of last century was under pressure, still most tuition was done in a very classical way, involving a lot of ex cathedra teaching. Slowly but gradually, a thorough change took place. There was a shift from knowledge to competence. Not only because education asked for change, but also because the professional world wanted this change.

At the moment, teaching is a chequered pattern of all possible methods, depending on the subject, but also on the learning outcomes. Somehow, a lot of these methods are part of social constructivism in which the individual parts can make a coherent unity to make a student capable to enter the shop floor.

In the scope of this article we have tried to show what it takes practically for a lecturer to adapt to this whole new way of teaching, in which he has to step off his traditional tribune and take a participatory stand at the side. From lecturer to coach, from mister know-it-all to knowledgeable facilitator. But - at the same time - it is massive and absorbing work.

Therefore, this transition is not always smooth because you have to learn as well. You have to throw off your old garments and put on your overalls, you have to roll up your sleeves and put your hand to the plough. Only then will furrows be deep enough to be everlasting and render a fruitful crop.

FRAMEWORK OF REFERENCE FOR INTERCULTURAL COMPETENCE FOR BUSINESS PURPOSES

'I am a critical and conscious citizen (1) and I can function flexibly (3) and interculturally (3) in an open and respectful manner (2) in the multicultural and diverse society (6) in which I live (4) and work (5)'

\begin{tabular}{|l|l|l|}
\hline \multicolumn{1}{|c|}{ Basic = knowing } & \multicolumn{1}{c|}{$\begin{array}{c}\text { Advanced }= \\
\text { understanding }\end{array}$} & Proficiency = applying \\
\hline \multicolumn{2}{|c|}{$\begin{array}{c}\text { 1 Critical awareness (attitude) } \\
\text { Can deal critically and consciously as an individual with the society in }\end{array}$} \\
which he/she lives \\
\hline $\begin{array}{l}\text { Notices that he/she lives } \\
\text { in a changing society }\end{array}$ & $\begin{array}{l}\text { Dares to question the } \\
\text { society in which he/she } \\
\text { lives }\end{array}$ & $\begin{array}{l}\text { Is aware of and has a } \\
\text { critical approach to the } \\
\text { society in which he/she } \\
\text { lives }\end{array}$ \\
\hline $\begin{array}{l}\text { Recognizes prejudices, } \\
\text { racist feelings and } \\
\text { attitudes within oneself } \\
\text { and others and knows the } \\
\text { cultural stereotypes }\end{array}$ & $\begin{array}{l}\text { Can make prejudices, } \\
\text { racist feelings and } \\
\text { attitudes within oneself } \\
\text { and others subject of } \\
\text { discussion and } \\
\text { understands the origin of }\end{array}$ & $\begin{array}{l}\text { Can prevent oneself and } \\
\text { others from prejudices, } \\
\text { racist feelings and } \\
\text { attitudes and can see } \\
\text { through the cultural } \\
\text { stereotypes }\end{array}$ \\
\hline
\end{tabular}




\begin{tabular}{|c|c|c|}
\hline & stereotypes & \\
\hline \multicolumn{3}{|c|}{$\begin{array}{l}2 \text { Openness - right to differ - respect for otherness (attitude) } \\
\text { Can deal with ambiguous situations, is open to others and can accept } \\
\text { pect possible differences }\end{array}$} \\
\hline $\begin{array}{l}\text { Recognizes other cultures } \\
\text { and cultural diversity }\end{array}$ & $\begin{array}{l}\text { Tolerates other cultures } \\
\text { and cultural diversity }\end{array}$ & $\begin{array}{l}\text { Functions within other } \\
\text { cultures and cultural } \\
\text { diversity }\end{array}$ \\
\hline $\begin{array}{l}\text { Recognizes otherness } \\
\text { (culture, class, gender, } \\
\text { age, health, sexual } \\
\text { inclination, ethnicity, } \\
\text { appearance, ...) }\end{array}$ & Accepts otherness & $\begin{array}{l}\text { Functions according to the } \\
\text { principles of equality }\end{array}$ \\
\hline $\begin{array}{l}\text { Recognizes culture shock } \\
\text { within oneself and others } \\
\text { when in contact with a } \\
\text { different culture }\end{array}$ & $\begin{array}{l}\text { Knows how to deal with } \\
\text { the problems of culture } \\
\text { shock }\end{array}$ & $\begin{array}{l}\text { Effectively overcomes the } \\
\text { problems of culture shock }\end{array}$ \\
\hline \multicolumn{3}{|c|}{$\begin{array}{l}\text { Can be flexible when dealing with realistic situations and demands and } \\
\text { can understand intuitively what other people think and feel in realistic situations }\end{array}$} \\
\hline $\begin{array}{l}\text { Is aware of past } \\
\text { experiences }\end{array}$ & $\begin{array}{l}\text { Learns from past } \\
\text { experiences }\end{array}$ & $\begin{array}{l}\text { Adapts to the actual } \\
\text { situation }\end{array}$ \\
\hline $\begin{array}{l}\text { Is willing to learn the } \\
\text { partner's language: } \mathrm{CEF}- \\
\text { A }\end{array}$ & $\begin{array}{l}\text { Is willing to learn the } \\
\text { partner's language: CEF - } \\
\text { B }\end{array}$ & $\begin{array}{l}\text { Is willing to learn the } \\
\text { business partner's } \\
\text { language: CEF - C }\end{array}$ \\
\hline $\begin{array}{l}\text { Notices that business } \\
\text { partners can react } \\
\text { differently }\end{array}$ & $\begin{array}{l}\text { Understands that business } \\
\text { partners can react } \\
\text { differently }\end{array}$ & $\begin{array}{l}\text { Accepts the other as a } \\
\text { coherent individual and } \\
\text { deals tactfully with } \\
\text { different reactions }\end{array}$ \\
\hline \multicolumn{3}{|c|}{$\begin{array}{l}4 \text { Communicative skill (skill) } \\
\text { Can communicate effe }\end{array}$} \\
\hline $\begin{array}{l}\text { Recognizes the } \\
\text { intercultural background } \\
\text { and possible problems in } \\
\text { written, oral and non- } \\
\text { verbal communication }\end{array}$ & $\begin{array}{l}\text { Understands the } \\
\text { intercultural background } \\
\text { and possible problems in } \\
\text { written, oral and non- } \\
\text { verbal communication }\end{array}$ & $\begin{array}{l}\text { Can prevent possible } \\
\text { intercultural problems in } \\
\text { written and oral } \\
\text { communication and in } \\
\text { non-verbal } \\
\text { communication }\end{array}$ \\
\hline \multicolumn{3}{|c|}{$\begin{array}{l}5 \text { Solution oriented attitude (skill) } \\
\text { Can think and act in a solut }\end{array}$} \\
\hline $\begin{array}{l}\text { Recognizes } \\
\text { misunderstandings and } \\
\text { conflicts, possibly related } \\
\text { to the cultural background }\end{array}$ & $\begin{array}{l}\text { Understands the origin of } \\
\text { misunderstandings and } \\
\text { conflicts, possibly related } \\
\text { to the cultural background }\end{array}$ & $\begin{array}{l}\text { Can prevent } \\
\text { misunderstandings and } \\
\text { conflicts }\end{array}$ \\
\hline $\begin{array}{l}\text { In individual situations, } \\
\text { makes an extra effort to } \\
\text { learn from }\end{array}$ & $\begin{array}{l}\text { As a rule makes an extra } \\
\text { effort to learn from } \\
\text { misunderstandings and }\end{array}$ & $\begin{array}{l}\text { Will purposely seek out } \\
\text { situations in which can be } \\
\text { learned from living, }\end{array}$ \\
\hline
\end{tabular}




\begin{tabular}{|c|l|l|}
\hline $\begin{array}{l}\text { conflicts. } \\
\text { misunderstandings and }\end{array}$ & conflicts. & $\begin{array}{l}\text { working or studying with } \\
\text { people from different } \\
\text { cultures or with a different } \\
\text { background }\end{array}$ \\
\hline \multicolumn{3}{|c|}{$\begin{array}{c}\text { 6 Cultural knowledge (knowledge) } \\
\text { Can acquire knowledge of a different culture and can use this }\end{array}$} \\
knowledge in actual situations \\
\begin{tabular}{|l|l|l|} 
Knows the concepts \\
relating tointerculturality
\end{tabular} & $\begin{array}{l}\text { Can see a link between } \\
\text { professional situations and } \\
\text { the concepts relating to } \\
\text { interculturality }\end{array}$ & $\begin{array}{l}\text { Can apply the concepts } \\
\text { relating tointerculturality } \\
\text { in professional situations }\end{array}$ \\
\hline $\begin{array}{l}\text { Recognizes the problems } \\
\text { of neglected target groups: } \\
\text { immigrants, asylum } \\
\text { seekers, underprivileged, } \\
\text { whom he/she has to deal } \\
\text { with in his/her working } \\
\text { environment } \\
\text { (subordinates, colleagues) }\end{array}$ & $\begin{array}{l}\text { Knows how to deal with } \\
\text { and understands the } \\
\text { problems of neglected } \\
\text { target groups }\end{array}$ & $\begin{array}{l}\text { Effectively deals with } \\
\text { people from neglected } \\
\text { target groups in a } \\
\text { spontaneous way }\end{array}$ \\
\hline $\begin{array}{l}\text { Recognizes the } \\
\text { sociocultural conventions } \\
\text { of target groups he/she } \\
\text { comes into contact with: } \\
\text { companies, expats, ... }\end{array}$ & $\begin{array}{l}\text { Understands the } \\
\text { sociocultural conventions } \\
\text { of the target groups he/she } \\
\text { comes into contact with }\end{array}$ & $\begin{array}{l}\text { Incorporates the } \\
\text { sociocultural conventions } \\
\text { of the target groups he/she } \\
\text { comes into contact with }\end{array}$ \\
\hline
\end{tabular}

\section{Works cited}

Baeten, M., Evaluatievoorkeuren en studieaanpak. Een pretest-posttest design in een leeromgeving met nieuwe assessmentvormen (Preferences of Assessment and Study Methods. A Pretest-Posttest Design in a Learning Environment with New Forms of Assessment), unpublished licentiate's thesis, Catholic University Louvain, 2007.

Bertels, U., et. al., , Ethnologie in der Schule. Eine Studie zur Vermittlung Interkultureller Kompetenz (Ethnology at School. A Research about Transfer of Intercultural Competence), Münster-New York-München-Berlin: Waxmann, 2004, series Praxis Ethnologie 1.

Bertels, U. de Vries S. \& Nolte N. (eds.), Fremdes Lernen. Aspekte interkulturellen Lernens im internationalen Diskurs (Foreign Learning. Aspects of Intercultural Learning in International Discourse), Münster-New York-München-Berlin: Waxmann, 2007, series Praxis Ethnologie 3.

Bruin, K., van der Heijde H. , Intercultureel onderwijs in de praktijk (Intercultural Training in Practice), Uitgeverij Coutinho (Bussum), 2007.

Burssens, P. and Van Loon C., Een simulatiespel als werk- en evaluatievorm (A simulation game as work and assessment form), Workshop ECHO, Antwerp, February 2007. 
Catteeuw, P. and Coutuer, M., 'Hogescholen werken aan interculturele communicatie. Portfolio Interculturele Communicatie in professionele bachelor' (University Colleges and Intercultural Communication. Portfolio for Intercultural Communication in the Curriculum Professional Bachelor), Delta. Tijdschrift voor Hoger Onderwijs, Brussels 8 (2005).

Catteeuw, P. and Coutuer, M., 'Een portfolio voor interculturele competenties.

Zoektocht naar een referentiekader interculturele communicatie' (A Portfolio for Intercultural Competences. In Search for a Framework of Reference for Intercultural Communication), Mores. Tijdschrift voor volkscultuur in Vlaanderen, 6-3 (2005).

Catteeuw, P. and Coutuer, M., 'Working with portfolios in a professional bachelor', The proceedings of the eEuroInclusion International Conference "Equal Chances for Any European Language”, Iasi (Romania), 30.09-02.10.2005, 2005.

Catteeuw, P. and Coutuer, M., 'Higher education and intercultural communication: Intercultural Communication Portfolio at the Professional Bachelor Level', in: Aalto, N. and Reuter E. (eds.), Aspects of Intercultural Dialogue. Theory Research-Applications, Köln: SAXA, 2006.

Catteeuw, P. and Coutuer M., 'Portfolio interculturele competentie' and 'Portofolio Kompetensi Interkultural' (Portfolio Intercultural Competence), in: Gustinelly E., Mursidah Y., Suhardi R. .\& Groeneboer K. (eds.), Tiga Puluh Lima Tahun Studi Belanda di Indonesia. Vijfendertig Jaar Studie Nederlands in Indonesië (Thirty-five years of Dutch Study in Indonesia), Depok: Kampus Universitas Indonesia, 2006.

Catteeuw, P. and Coutuer, M., 'Higher education and intercultural communication: Intercultural Communication Portfolio at the Professional Bachelor Level', in: G.S. Ioannidis, S.G. Antonopoulos, D.M. Garyfallidou, A.C. Tsiokanos (eds.), eStream Conference on Streaming Technology in Education in Europe, 14-16 June, Patras/Greece Patras: Patras University Press, 177-184.

Catteeuw, P., A Framework of Reference For Intercultural Competence. A 21st century Flemish Experiment in Capacity Building in Formal Education, FARO, 2012..

Catteeuw, P., Do engineers need to be interculturally competent?, in Management Facing New Technologies Challenges, Boekarest, 2013.

Catteeuw, P., Portfolio Assessment and Intercultural Competence, in The $9^{\text {th }}$ International Scientific Conference eLearning and software for Education, Boekarest, 2013, 265-271.

Cooper, P. J., Calloway-Thomas C., and J. Simonds C., Intercultural Communication. A Text with Readings, Pearson Education (Boston), 2007.

De Backe, H., Onderwijzen met souplesse: interactieve werkvormen. Flexibiliseren in onze hogeschool (Flexible Teaching at Our University College: Interactive Methods), Antwerpen: Karel de Grote-Hogeschool, 2005.

De Vito, J.A., The Interpersonal Communication Book, Pearson Education (Boston), 2007.

Eismann, V., Erfolgreich in der interkulturellen Kommunikation. Trainingsmodul (Successful in Intercultural Communication. Training module), Cornelsen (Berlin), 2007.

Meeus, W. and Van Looy, L., Portfolio zonder blozen. Het instrument doorgelicht vanuit 
het perspectief van de lerarenopleiding, Antwerpen-Apedoorn: Garant, 2005.

Pinto D., Intercultural Communication. A three-step method for dealing with differences, Garant, 2000.

Sercu L. (ed.), National helpdesks for intercultural learning materials. A guideline, Parel (Utrecht), 1999.

van Tartwijk, J. Driessen E., Hoeberigs B., Kösters J., Ritzen M., Stokking K., van der Vleuten C., Werken met een elektronische portfolio (Using an Electronic Portfolio), Groningen/Houten: Wolters-Noordhoff, 2003.

${ }^{\mathrm{i}}$ Most articles can be downloaded from the LinkedIn profile of the author.

${ }^{i i}$ In this respect we refer to Hilde De Backer, Onderwijzen met souplesse: interactievewerkvormen.

Flexibiliseren in onzehogeschool (Flexible Teaching at Our University College: Interactive

Methods), Antwerpen: Karel de Grote-Hogeschool, 2005.

iii Because of readability we will systematically use he for students, though we mean both male and female students.

${ }^{\text {iv }}$ A selection of recent or successful material:

Bruin, K. and van der Heijde H., Intercultureelonderwijs in de praktijk(Intercultural Training in Practice), Uitgeverij Coutinho, Bussum, 2007.

Eismann, V., Erfolgreichin der Interkulturellen Kommunikation. Trainingsmodul (Successful in Intercultural Communication. Training module), Cornelsen, Berlin, 2007. This module even introduces the levels of the Common European Framework of Reference for Languages. This course is meant for the levels B2/C1.

De Vito, J. A., The Interpersonal Communication Book, Pearson Education, Boston, 2007.

Cooper, P. J., Calloway-Thomas C. and J. Simonds C., Intercultural Communication. A Text with Readings, Pearson Education, Boston, 2007.

Sercu, L. (ed.), National helpdesks for intercultural learning materials.A guideline, Parel Utrecht, 1999.

${ }^{v}$ Pinto, D., Intercultural Communication. A three-step method for dealing with differences, Garant, 2000

${ }^{v i}$ More than 100 libraries had to close down: see http://www.taalblad.be/e-zine/nieuws/veel-

vlaamse-bibliotheken-gaan-dicht/1131.html (visited: 12-12-13)

viiB Blackboard.

viii Catteeuw P., 2012, 10-24.

ix Burssens, P. and Van Loon C., Eensimulatiespelalswerk- en evaluatievorm (A simulation game as work and assessment form), Workshop ECHO, Antwerp, February 2007.

${ }^{\mathrm{x}}$ Literature about portfolio: Meeus W. and Van Looy L., Portfolio zonderblozen. Het instrument doorgelichtvanuit het perspectief van de lerarenopleiding, Antwerpen-Apedoorn: Garant, 2005, o.c., and van Tartwijk J., Driessen E., Hoeberigs B., Kösters J., Ritzen M., Stokking K. and van der Vleuten, C., Werken met eenelektronische portfolio, Groningen-Houten: Wolters-Noordhoff, 2003.

${ }^{\mathrm{xi}}$ Marleen Coutuer, lecturer at the university college Artveldehogeschool Ghent.

xii van Tartwijketalii J., Werken met eenelektronisch portfolio (Using an Electronic Portfolio) Groningen/Houten: Wolters-Noordhoff, 2003), 62-63.

${ }^{x i i i}$ Bertels U., et al., Ethnologie in der Schule.EineStudiezurVermittlungInterkulturellerKompetenz (Ethnology at School.A Research about Transfer of Intercultural Competence), Münster-New York-München-Berlin: Waxmann, 2004, series Praxis Ethnologie 1 and Bertels U., de Vries S. \& Nolte N. (eds.), FremdesLernen. AspekteinterkulturellenLernensiminternationalenDiskurs (Foreign Learning. Aspects of Intercultural Learning in International Discourse), Münster-New York-München-Berlin: Waxmann, 2007, series Praxis Ethnologie 3 
${ }^{\text {xiv }}$ Baeten, M., Evaluatievoorkeuren en studieaanpak. Eenpretest-posttest design in eenleeromgeving met nieuweassessmentvormen (Preferences of Assessment and Study Methods. A Pretest-Posttest Design in a Learning Environment with New Forms of Assessment), unpublished licentiate's thesis, Catholic University Louvain, 2007.

${ }^{\mathrm{xv}}$ We haven't systemized these results, but boy students seem to overrate themselves, whereas girl students tend to underestimate themselves. 


\title{
CREATIVITY IN COOPERATION - FOR INTEGRATING SUSTAINABLE DEVELOPMENT IDEAS INTO TEACHER PRACTICE
}

\author{
INTA RATNIECE \\ Riga Teacher Training and Educational Management Academy, Latvia \\ AGNESE RATNIECE \\ Pumpuri Secondary School, Latvia
}

\begin{abstract}
:
Teachers as creative sustainable development promoters should cooperate by empowering the link between generations, implementing development, satisfying the needs of the present generation, and securing the ability of future generations to meet their own needs. Aim of the study. To facilitate development of innovative practices in education and training at tertiary level. Materials and methods. Analysis of theoretical sources, an ERASMUS Project IP uniting in cooperation educators from 11 countries. Results. Innovative ICT-based content, pedagogies and practice for SD. Conclusions. Teachers widespread SD more creatively and professionally if they participate in international collaboration projects involving SD issues.
\end{abstract}

Keywords: cooperation, innovation, integration, link with community, sustainable development, teachers' teamwork.

\section{Introduction}

Teachers as creative community promoters and sustainable development widespreaders should cooperate with colleagues, students and community for empowering the link between generations, implementing development, satisfying the needs of the present generation, and enhancing the ability of future generations to meet their own needs. Nowadays, it is most essential that all people with a sense of responsibility turn their attention to both the aims and the means of education to develop the ways in which educational policies can help to create a better world by contributing to sustainable human development, mutual understanding among people and a renewal of practical democracy.

A quality education must reflect learning in relation to the learner as a creative 'individual, family and community member and a part of the world society. A quality education understands the past, is relevant to the present and has a view to the future. Quality education relates to knowledge building and the 